\title{
The Indonesian Pronunciation Mistakes of Chinese Students from Yunnan Minzu University
}

\author{
Meilan Xu \\ Indonesian Language and Literature Education of Graduate \\ School \\ Universitas Negeri Yogyakarta \\ Yogyakarta, Indonesia \\ meilanxu.2018@student.uny.ac.id
}

\author{
Teguh Setiawan \\ Faculty of Language and Arts \\ Universitas Negeri Yogyakarta \\ Yogyakarta, Indonesia \\ teguh_setiawan@uny.ac.id
}

\begin{abstract}
Abtract - There are several Indonesian pronunciation mistakes of the Chinese students who are majoring in Indonesian. This research is aimed to explain the Indonesian pronunciation mistakes of the students, to solve those mistakes, and to give some useful suggestions about Indonesian pronunciation skills to Chinese people. The method used in this research is qualitative research. The techniques that were used to collect data are observation and interview. Analysis used in this research including: collecting data, identifying mistakes, classifying mistakes and descripting mistakes. The mistakes include vowel and consonant pronunciation. The results of this research include five aspects. First, the mistakes of vowel pronunciation about the letter $\langle\mathrm{e}\rangle$. Second, the mistakes of pronunciation of voiced phonemes [b], [d], and [g]. Third, the mistakes of the phonemes $[\tilde{\mathbf{n}}],[\&]$ and $[\mathbf{r}]$. Fourth, the mistakes of pronunciation of the unreleased stops $\langle\mathrm{t}\rangle,\langle\mathrm{d}\rangle,\langle\mathrm{k}\rangle$ and $\langle\mathrm{g}\rangle$. Fifth, the mistakes of pronouncing the consonant cluster $\langle\mathrm{mb}\rangle$ in the beginning of words and the consonant $\langle\mathrm{h}\rangle$ in the end of words.
\end{abstract}

Keywords -Chinese students; Indonesian; Pronunciation; Mistakes

\section{INTRODUCTION}

As a big Country, Indonesia is more and more important in the world. Thus Indonesian is becoming a language which is learnt in many countries nowadays. China is one of the countries which have many universities offering an Indonesian major. Yunnan Minzu University is one of the universities that opened this major.

As we know, learning languages always begin with their pronunciation. For the students who are majoring in Indonesian language, pronunciation is the first step of their learning. The reason to learn prununciaton of languages as Tang (2008:35) said, pronunciation is the language itself, it is the basic of language learning and usage. In addition, pronunciation will influence the other fields of language learning. Thus, learning pronunciation is not noly the first step in learning a foreign language, but also is the most difficult and important step.

Indonesian is a major that has been opened by Yunnan Minzu University in 2011. There are many students who graduate in this major each year. Even though the process of learning pronunciation in Yunnan Minzu University is formal and takes a long time. But the students still have some pronunciation mistakes after pronunciation learning, even after graduate. Those mistakes include vowel and consonant pronunciation. The students uncorrect vowel and consonant pronunciation influence their learning and usage of Indonesian, for instance, listening, speaking, reading and writting. Indonesian language has been opened in Yunnan Minzu University for six years until 2017, but the problem of students' pronunciation has not been worked out. What's more, there are lack of researches that analyze the problem of Chinese students' Indonesian pronunciation. Therefore this research is done to organize the pronunciation mistakes that appeared. Researcher hopes that Indonesian leaners and instructors can use this research in their learning and teaching.

Before discussing the pronunciation mistakes that made by Chinese students. People need to know the relation of first language (F1) and target language (TL) and any linguistic knowledge that the learners have. Ringbom \& Jarvis (2009:106) said that foreign language learners tend to look for the similarities between the TL (Target Languae) and the prior linguistic knowledge that they have. Moreover, at the early stages of learning, L1(First Language) is the main source for perceiving linguistic similarities, because of the limitations of the TL. However, if learner acquires the other language on a high proficiency (especially this language retated with TL), it will be an important element that will influence TL learning. Therefore, Chinese students who are majoring in Indonesian are certain to be affected by their L1 (Chinese), and also they are influenced by the other foreign language, that is English (English is a compulsory foreign language in China).

Chinese belongs to the Sino-Tibetan language family (Charles \& Thompson, 2009:703). However Indonesian belongs to the Austronesian language family (Tadmor, 2009:791). There are many differences in phonetics system in these two languages. Here are the Standard Chinese and Indonesian phoneme tables (I-V) 
TABLE 1. VOWELS IN STANDARD CHINESE

\begin{tabular}{|c|c|c|c|c|c|c|c|c|}
\hline \multirow[t]{3}{*}{ Tongue position } & \multicolumn{3}{|l|}{ Apical vowel } & \multicolumn{5}{|l|}{ Blade vowel } \\
\hline & \multirow[t]{2}{*}{ Front } & \multirow[t]{2}{*}{ Middle } & \multirow[t]{2}{*}{ Back } & \multicolumn{2}{|l|}{ Front } & \multirow{2}{*}{$\begin{array}{l}\text { Middle } \\
\text { Unrounded }\end{array}$} & \multicolumn{2}{|l|}{ Back } \\
\hline & & & & Unrounded & Rounded & & Unrounded & Rounded \\
\hline High & 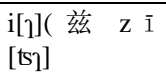 & & $\mathrm{i}[\mathrm{2}]($ 知 zhi [tš ]) & $\mathrm{i}[\mathrm{i}]$ & $\ddot{\mathrm{u}}[\mathrm{y}]$ & & & $\mathrm{u}[\mathrm{u}]$ \\
\hline Half tall & & $\operatorname{er}[\curvearrowright]$ & & & & & $\mathrm{e}$ (可 $\mathrm{ke}[\gamma]$ ) & $\mathrm{O}[\mathrm{o}]$ \\
\hline Half & & & & ê(㶼吕i $[\varepsilon]$ ) & & & & \\
\hline Half low & & & & & & & & \\
\hline Low & & & & & & $\mathrm{a}$ a $\mathrm{a}]$ & & \\
\hline
\end{tabular}

TABLE II. SEMI VOWELS IN STANDARD CHINESE

\begin{tabular}{|l|l|l}
\hline$[j]$ & {$[\mathrm{w}]$} & {$[\mathrm{u}]$} \\
\hline
\end{tabular}

Borong \& Yudong (2007:33)

TABLE III. CONSONANTS IN STANDARD CHINESE

\begin{tabular}{|c|c|c|c|c|c|c|c|c|c|c|c|c|c|c|c|c|}
\hline & & & Labial & & & & Front & & Alve & & Retı & & Coro & & Dorsc & \\
\hline & & & Bilabia & & Labiod & & & & & & & & & & & \\
\hline Manner o & ticulation & & 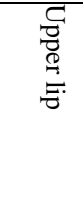 & 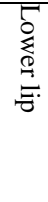 & 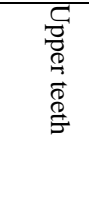 & 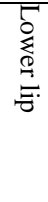 & $\begin{array}{l}\overrightarrow{\overrightarrow{0}} \\
\stackrel{\sigma}{0} \\
\stackrel{0}{0} \\
\vec{\theta}\end{array}$ & 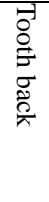 & $\begin{array}{l}\overrightarrow{0} \\
\stackrel{0}{\sigma} \\
\tilde{0} \\
\tilde{0} \\
\vec{\theta}\end{array}$ & 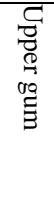 & 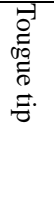 & 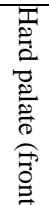 & 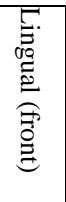 & 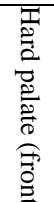 & 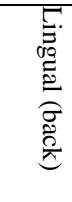 & 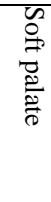 \\
\hline Stop & Voiceless & Unaspirated & $\mathrm{b}[\mathrm{p}]$ & & & & & & $\mathrm{d}[\mathrm{t}]$ & & & & & & $\mathrm{g}[\mathrm{k}]$ & \\
\hline & & Aspiration & $\mathrm{p}\left[\mathrm{p}^{\mathrm{h}}\right]$ & & & & & & $\mathrm{t}\left[\mathrm{t}^{\mathrm{h}}\right]$ & & & & & & $\mathrm{k}\left[\mathrm{k}^{\mathrm{h}}\right]$ & \\
\hline Affricate & Voiceless & Unaspirated & & & & & $z[\mathrm{~s}]$ & & & & $\mathrm{zh}[\mathrm{t}$ & & $\mathrm{j}[\mathrm{t} 6]$ & & & \\
\hline & & Aspiration & & & & & $\mathrm{c}\left[\mathrm{ts}^{\mathrm{h}}\right]$ & & & & $\operatorname{ch}[\mathrm{t}$ & & $\mathrm{q}\left[\mathrm{t} 6^{\mathrm{h}}\right.$ & & & \\
\hline Fricative & Voiceless & & & & $\mathrm{f}[\mathrm{f}]$ & & $\mathrm{s}[\mathrm{s}]$ & & & & $\operatorname{sh}[\mathrm{s}$ & & $x[6]$ & & $\mathrm{h}[\mathrm{x}]$ & \\
\hline & Voiced so & & & & & & & & & & $\mathrm{r}[\mathrm{z}]$ & & & & & \\
\hline Nasal & Voiced so & & $\mathrm{m}[\mathrm{m}]$ & & & & & & $\mathrm{n}[\mathrm{n}]$ & & & & & & & \\
\hline Lateral & Voiced so & & & & & & & & $1[1]$ & & & & & & & \\
\hline
\end{tabular}

Borong \& Yudong (2007:29)

TABLE IV. VOWELS IN INDONESIAN

\begin{tabular}{|l|l|l|l|l|}
\hline Tongue position & Frount & Middle & \multicolumn{2}{l|}{ Back } \\
\cline { 2 - 5 } & Unrounded & Unrounded & Rounded & \\
\hline $\begin{array}{l}\text { upper } \\
\text { High } \\
\text { below }\end{array}$ & $\mathrm{i}[\mathrm{i}]$ & & $\mathrm{u}[\mathrm{u}]$ & \\
\hline $\begin{array}{l}\text { upper } \\
\begin{array}{l}\text { Middle } \\
\text { below }\end{array}\end{array}$ & & & & \\
\hline Low & $\mathrm{e}[\mathrm{e}]$ & $\mathrm{e}[$ ə] & & $\mathrm{o}[\mathrm{o}]$ \\
\\
\hline
\end{tabular}

Arrange from Chaer (2009:68)

TABLE V. CONSONANTS IN INDONESIAN

\begin{tabular}{|l|l|l|l|l|l|l|l|l|l|}
\hline \multicolumn{2}{|l|}{ Manneref articulation } \\
place of Articulation
\end{tabular}




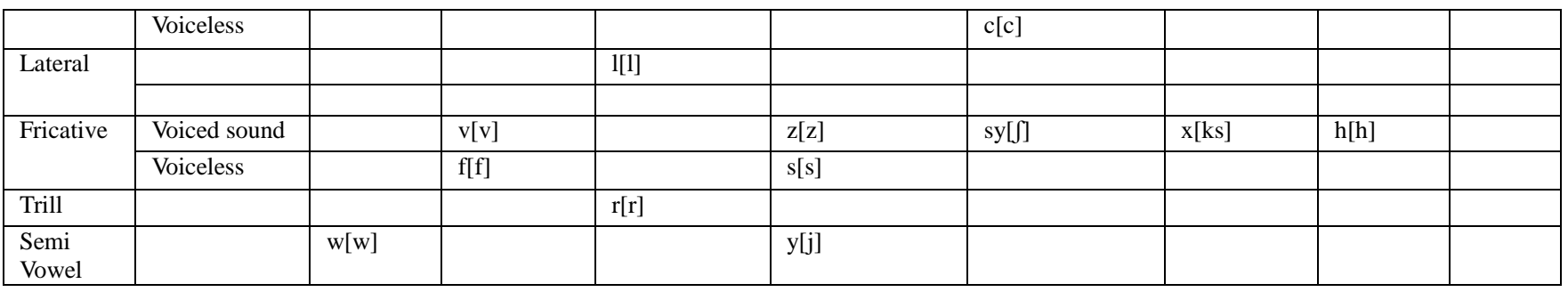

Chaer (2009:72)

Based on tables above, Standard Chinese vowels and Indonesian vowels have more similarities, but consonants between these two language have more differences.

\section{RESEARCH METHOD}

This research is a qualitative research. This research is based on factual data which was collected by the researcher. The subject of this research is 25 students who learned Indonesian in Yunnan Minzu University from 2013 to 2017. The object is Indonesian pronunciation mistakes from these students. The techniques of data collection were observations and interviews with the students who had studied Indonesian for 4 years. The Researcher has conducted these observations and interviews, because the researcher is one of the students majoring in Indonesian in Yunnan Minzu University starting from 2013. The prosess of this research was collecting data, identifying mistakes, classifying mistakes and descripting mistakes.

\section{RESULTS AND DISCUSSION}

\section{A. The Mistakes of Vowel Pronunciation}

There are 9 vowels in Indonesian, including [a], [ə], [i], [o], [u], [e], [au], [ai] and [oi] (PrimaPena, 2003: 802), and there is no difference between long vowels and short vowels. In standard Chinese, the basic vowels include: [a], $[\gamma] /[$ ə], [i], [o], [u], [ع], [1], [ح], [y] and [ə] (see table I). In addition, standard Chinese have 13 diphthongs: ai [ai], ei

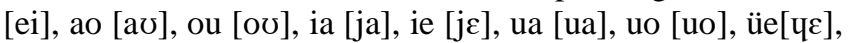
iao [jav], iu [jov], uai [wai] and ui[wei]. Those vowels also have minute variations with different initials (consonants). Except oi [oi], the other 8 vowels in Indonesian are exist in standard Chinses. It seems that Chinese students should not have problem to pronuounce Indonesian vowels.

However, it is confusing for Chinese students when a word that has the letter $\langle\mathrm{e}\rangle$. The reason is in Inodnesian, the letter $\langle\mathrm{e}\rangle$ represents two phonemes, they are [ə] and [e]. When students meet the words which have letter $\langle\mathrm{e}\rangle$, they are not sure if it should be pronounced as [ə] or [e]. Sometimes they pronounce e [ə] as e [e], sometimes they pronounce e [e] as e [ə]. The following Table (VI) provides the mistake examples of vowel pronunciation of Chinese students.

TABLE VI. THE MISTAKES OF VOWEL PRONUNCIATION

\begin{tabular}{|c|c|c|}
\hline $\begin{array}{ll}\text { No. } & \text { Vowel }<\mathrm{e}> \\
\end{array}$ & $\mathrm{e}[\mathrm{\partial}] \rightarrow \mathrm{e}[\mathrm{e}]$ & $\mathrm{e}[\mathrm{e}] \rightarrow \mathrm{e}[\mathrm{\partial}]$ \\
\hline 1 & sepatu: [səpatu] $\rightarrow$ [sepatu] & kena:[kena] $\rightarrow[$ kəna $]$ \\
\hline 2 & mereka:[məreka] $\rightarrow[$ mereka] & macet: $[$ macet $] \rightarrow[$ macət $]$ \\
\hline 3 & merapi:[mərapi] $\rightarrow[$ merapi] & defile:[defile] $\rightarrow[$ dəfilə] \\
\hline 4 & sesuatu: [səsuatu] $\rightarrow[$ sesuatu] & recek:[recek] $\rightarrow[$ rəcek $]$ \\
\hline 5 & apel:[apol $] \rightarrow[$ apel] $]$ & mebel:[mebəl $] \rightarrow[$ məbəl $]$ \\
\hline
\end{tabular}

\section{B. The Mistakes of Consonant Pronunciation}

In the field of consonants, Chinese students have several mistakes. Comparing table III with table V, the consonants of Standard Chinese and Indonesian language have many differences. There are not voiced bilabial [b], voiced apikolaveolar [d], voiced dorsovelar [g], laminopalatal nasal ny [ñ], dorsovelar nasal [n], voiced laminopalatal affricate [d]], voiceless laminopalatal affricate [c], voiced labiodental fricative $[\mathrm{v}]$, voiced laminoalveolar ficative $[\mathrm{z}]$, voiced laminopalatal fricative [S], voice dorsovelar fricative [ks] and trill $[\mathrm{r}]$ in standard Chinese. Furthermore, Indonesian and standard Chinese have different syllables system, acording to Charles \& Thompson (2009:707) the consonants that can be final consonants in Chinese are only nasals, specifically $<\mathrm{n}>[\mathrm{n}]$ and $<\mathrm{ng}>[\mathrm{n}]$ ). However, in Indonesian vocabularies all the consonants can be final consonants in a word except [ $\tilde{n}]$.

The following part is to discuss several cases of Chinese students' Indonesian consonant pronunciation mistakes.

First, the students have mistakes in voiced sound consonants. When the Chinese students pronounce [b], [d], and $[\mathrm{g}]$ in Indonesian, they tend to pronounce them as [p], $[\mathrm{t}]$, and $[\mathrm{k}]$. Second, Chinese students pronounce incorrectly

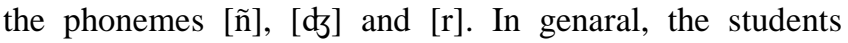

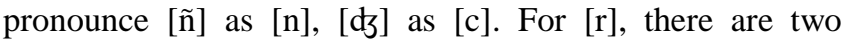
typical mistakes, one of them is if the $[\mathrm{r}]$ is in the middle or the end of a word, the students tend to pronounce it as [1]; the other case is if the [r] located in beginning of a word, the students tend to pronounce it as [tr]. The reason is that Standard Chinese doesn't have these phonemes. When it is hard to pronounce these phonemes, the students will tend to pronounce them as the sounds which they can. Third, 
Chinese students have mistakes in pronouncing the unreleased stop, such as $\langle\mathrm{t}\rangle,\langle\mathrm{d}\rangle,\langle\mathrm{k}\rangle$, and $\langle\mathrm{g}\rangle$. Most of the time, the students tend not to pronounce these unreleased stops. Fifth, the students can not pronounce two consonants very well: the consonant cluster $\langle\mathrm{mb}\rangle$ which is in the beginning of words, and $\langle\mathrm{h}\rangle$ in the end of the words.
Generally, they change the consonant cluster $\langle\mathrm{mb}\rangle$ with $\langle\mathrm{b}\rangle$. For $\langle\mathrm{h}\rangle$, some students do not pronounce it, some of them pronounce it as [ha]. The following Table (VII) provides the mistake examples of conconant pronunciation of Chinese students.

TABLE VII. THE MISTAKES OF CONSONANT PRONUNCTION

\begin{tabular}{|c|c|c|c|c|}
\hline \multicolumn{5}{|c|}{ Catagories } \\
\hline No. & $\begin{array}{l}\text { Pronunciation mistakes } \\
\text { voiced bilabial phonemes: } \\
{[\mathrm{b}],[\mathrm{d}] \text {, and }[\mathrm{g}]}\end{array}$ & $\begin{array}{l}\text { Pronunciation mistakes of laminopalatal } \\
\text { nasal phonemes [ñ }] \text {, [d] , and the trill } \\
\text { phoneme }[\mathrm{r}]\end{array}$ & $\begin{array}{l}\text { Pronunciation mistakes } \\
\text { of unreleased stop; }\langle\mathrm{t}\rangle \text {, } \\
\langle\mathrm{d}\rangle,\langle\mathrm{k}\rangle \text { and }\langle\mathrm{g}\rangle\end{array}$ & $\begin{array}{l}\text { Pronunciation mistakes of consonant } \\
\text { cluster }\langle\mathrm{mb}\rangle \text { in the beginning of words } \\
\text { and }\langle\mathrm{h}\rangle \text { in the end of words }\end{array}$ \\
\hline \multirow[t]{3}{*}{1.} & $\begin{array}{l}{[\mathrm{b}] \rightarrow[\mathrm{p}]:} \\
<\text { beda }>[\text { beda }] \rightarrow[\text { peta }] \\
<\text { bentuk }>[\text { bentuk }] \rightarrow[\text { pentuk }]\end{array}$ & $\begin{array}{l}{[\tilde{n}] \rightarrow[\mathrm{n}]:} \\
<\text { nyanyi }>[\text { ñañi }] \rightarrow[\text { nani }] \\
<\text { nyonya }>[\text { ñoña }] \rightarrow[\text { nona }]\end{array}$ & $\begin{array}{l}<\mathrm{t}>\text { disappear: } \\
<\text { mulut }>\rightarrow<\text { mulu }> \\
<\text { alat }>\rightarrow<\text { ala }>\end{array}$ & $\begin{array}{l}<\mathrm{mb}>\rightarrow<\mathrm{b}>\text { : } \\
<\mathrm{mbak}>\rightarrow<\text { bak }> \\
<\mathrm{mbah}>\rightarrow<\text { bah }>\end{array}$ \\
\hline & $\begin{array}{l}{[\mathrm{d}] \rightarrow[\mathrm{t}]:} \\
<\text { datang }>[\text { datan }] \rightarrow[\text { tatan }] \\
<\text { daerah }>[\text { daerah }] \rightarrow[\text { taerah }]\end{array}$ & $\begin{array}{l}{[\mathrm{d}] \rightarrow[\mathrm{c}]:} \\
<\text { jelas }>[\text { dzolas }] \rightarrow[\text { colas }] \\
<\text { banjir }>[\text { bandzir }] \rightarrow[\text { bancir }]\end{array}$ & $\begin{array}{l}<\text { d }>\text { disappear: } \\
<\text { abad }>\rightarrow<\text { aba }> \\
<\text { abjad }>\rightarrow<\text { abja }>\end{array}$ & $\begin{array}{l}<\text { h }>\text { disappear or to be }<\text { ha }>\text { : } \\
<\text { marah }>\rightarrow<\text { mara }>/<\text { maraha }> \\
<\text { abilah }>\rightarrow<\text { abila }>/<\text { abilaha }>\end{array}$ \\
\hline & $\begin{array}{l}{[\mathrm{g}] \rightarrow[\mathrm{k}]:} \\
<\text { gelas }>\text { [gəlas }] \rightarrow[\text { kəlas }] \\
<\text { gelap }>\text { [gelap }] \rightarrow[\text { kelap }]\end{array}$ & $\begin{array}{l}{[\mathrm{r}] \rightarrow[1] /[\mathrm{tr}]:} \\
<\text { terong }>[\text { terong }] \rightarrow[\text { telong }] \\
<\text { ajar }>[\text { ajar }] \rightarrow[\text { ajal }] ; \\
<\text { rahasia }>[\text { rahasia }] \rightarrow \text { trahasia }] \\
<\text { remdam }>[\text { rendam }] \rightarrow[\text { trendam }]\end{array}$ & $\begin{array}{l}<\text { k>disappear: } \\
<\text { nggak }>\rightarrow<\text { ngga }> \\
<\text { agak }>\rightarrow<\text { aga }>\end{array}$ & \\
\hline & & & $\begin{array}{l}\text { <g> disappear: } \\
<\text { gudeg }>\rightarrow<\text { gude }>\end{array}$ & \\
\hline
\end{tabular}

C. The Factors That Causing Pronunciation Mistakes

Based on the results of the study, there are several factors causing Indoneisan pronunciation mistakes for the students from Yunnan Minzu University, who are majoring in Indonesian. The factors are the L1 of the students, their age and limitation of vocabularies. L1 (Standard Chinese) and L2 (English) infulences the pronunciation on students, but the biggest influence is from Standard Chinese. It is because of the fact that an adult language learner' pronunciation is always influenced by his/her L1 when learning a foreign language (Bing, Yang \& Xiaonjuan, 2013:62).

In the pronunciation of vowels, there are not many mistakes, the only mistake is mixing of the pronunciations of [e] with [ə]. Because these two phonemes are written with the same letter $\langle\mathrm{e}\rangle$ in Indonesian, it confuses students at the early stage of learning. It is the time that students' vocabularies are limited, they don't know which word with the letter 〈e $\rangle$ should be pronounced with [o] or [e]. However, when their Indonesian is already fluent, this mistake is made less frequently. In addition, there are no mistakes in the pronunciation of other vowel phonemes, such as [a], [i], [o], and [u], [ai], [au] and [oi]. The reason is that those phonemes are similar with which in Standard Chinese. Even though the vowel [oi] which have not exist in standard Chinese, the students still can pronounce it correct, because [oi] exist in English, and Chinese students learn English for years.

In the classification of consonant pronunciation, there are more mistakes. Students can not pronounce some phonemes very well, like the phonemes [b], [d], and [g]. The reason is that in Standard Chinese, there are no voised phonemes [b], [d] and [g], but only the unaspirated voiseless phonemes $[\mathrm{p}],[\mathrm{t}]$ and $[\mathrm{k}]$ that are similar. So Chinese students tend to pronounce them as the phonemes

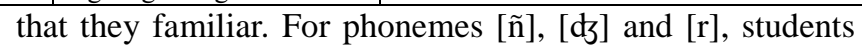
tend to pronounce as the othe phonemes that exist in Indonesian which easier to pronounce. For the unreleased stops pronunciation mistakes, the reason is in standard Chinese, the final phonemes in a word only are nasal phonemes [n] and [y]. It means standard Chinese doesn't have the unreleased stops $\langle\mathrm{t}\rangle,\langle\mathrm{d}\rangle,\langle\mathrm{k}\rangle$ and $\langle\mathrm{g}\rangle$. In addition, Standard Chinese has no words that begin with the consonant cluster $\langle\mathrm{mb}\rangle$ and words which end in $\langle\mathrm{h}\rangle$. Thus it is difficult for the students to pronounce the words that have those elements. However, for some consonants that are also not exist in Standard Chinese, most students can still pronounce them correct, such as the unreleased stop $\langle\mathrm{b}\rangle$ and $\langle\mathrm{p}\rangle$, the phonems $[\mathrm{v}],[\mathrm{z}],[\mathrm{J}],[\mathrm{j}],[\mathrm{h}]$ and $[\mathrm{ks}]$. Due to those cases exist in English, Chinese college students learn English for years, most of them can pronounce these phonemes very well. For phoneme [c], it is similar with phonem [t6] in standard Chinese, Chinese students can pronounce it correct too. The other consonant phonemes, such as [p], [t], [k], [f], [s], [m], [n], [1] and [w] are exist in standard Chinese, so there are no pronunciation mistakes that made by Chinese students.

\section{CONCLUSIONS}

Many people think that a foreign language or L2 should be learned when you are younger, because if the learner is younger, his/her pronunciation will be as pure as a native speaker's. But an adult leaner always has the limitation of age. However an adult's speech system is still plastic, and its foreign language (or second language) voice perception and output ability still has the potential to gradually increase (Flege, 2007:366). Even though not all the pronunciation problems could be solved through conventional teaching (Bing, Yang \& Xiaonjuan, 2013:63), but at least the learners can reduce mistakes in their 
language pronunciation. The students who are majoring in Indoneisan from Yunnan Minzu University already adults when they begin to learn Indonesian. So if those Chinese students want to reduce the pronunciation mistakes of Indonesian language they should practice harder. To do it, they should find some radio and video materials to practice. In addiction, L1 (Standard Chinese) and L2 (English) influence Chinese students' Indonesian pronounciation, there are help and interfere with L1. But from L2, there is more help than interference. Actually Chinese students avoided many pronunciation mistakes that made by the other foreigners when speaking Indonesian, for example, the facilitative sounds in Indonesian. It showes that the students actually master Indonesian pronunciation. The deficiencies that were above are the most difficult to overcome for them.

For the instructors who are teaching Indonesian to Chinese students also need to be careful the different phonetic systems of standard Chinese and Indonesian. If possible, the instructors need to point out the different sounds between Indonesian and standard Chinese, then help the students reduce the pronunciation mistakes.

\section{REFERENCES}

Bing, C. Yang, Z. \& Xiaonjuan, Z. (2013). Yu yin xue xi de shen jing ji zhi yan jiu ji qi zai jiu zheng wai yu kou yin de zuo yong. Jurnal Foreign Language Education, 38(4), 62-66. retrieved from file://C:/Users/Administrator/Desktop/学匀 /kelas\%20akademik/jurnal\%20kelas\%20knb/翻译参考文献/语音 学习的神经机制研究及其在纠正外语口音中的应用.pdf.

Borong, H. \& Yudong, L. (2007). Xian dai han yu. Beijing: Gao deng jiao yu chu ban she.

Chaer, A. (2009). Fonologi bahasa Indonesia. Jakarta: Rineka Cipta.

Charles, N. L. \& Thompson, A. S. (2009). Chinese, In Bernard Comrie (Eds.), The World's Major Languages (2-nd edition) (page 703-723). Abingdon: Routledge.

Flege, J. E. (2007). Language contact in bilingualism: Phonetic system interactions [J] . Laboratory Phonology, 2007 (9) : 353-382.

PrimaPena, T. (2003). Kamus Besar Bahasa Indonesia. Jakarta: Gitamedia Press.

Ringbom, H. \& Jarvis, S. (2009). The Importance of Cross-Linguistic Similarity in Foreign Language Learning, in H. Long \& J. Catherine (Eds.), The Handbook of Language Teaching (page 106-118). Chichester: John Wiley \& Sons, Ltd.

Tadmor, U. (2009). Malay-Indonesian, In Bernard Comrie (Eds.), The World's Major Languages (2-nd edition) (page 791-818). Abingdon: Routledge.

Tang, C. (2008). Dui wai Han yu jiao xue mu di, yuanze, fangfa. Beijing: Beijing yuyan da xue chu ban she. 